\title{
PERILAKU OFF TASK DALAM PEMBELAJARAN
}

\author{
Muhammad Arief Maulana
}

Program Studi Bimbingan dan Konseling, Universitas Veteran Bangun Nusantara

Email: maulgonzales89@gmail.com

\begin{tabular}{|c|c|}
\hline Article Info & 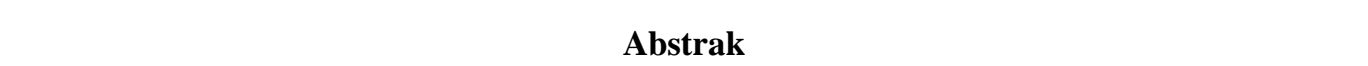 \\
\hline $\begin{array}{l}\text { Available online } \\
15.06 .2019\end{array}$ & $\begin{array}{l}\text { Tujuan penelitian ini adalah untuk memberikan pemahaman kepada pembaca mengenai } \\
\text { sikap dan perilaku siswa yang tidak mendukung proses pembelajaran (perilaku off task). Perilaku } \\
\text { off task yang sering muncul dan mengganggu proses pembelajaran di kelas. Penelitian ini adalah } \\
\text { penelitian pustaka,dengan menggunakan analisis deskripti analitik. Hasil penelitian menunjukkan } \\
\text { bahwa perilaku off task sering terjadi dalam proses pembelajaran terutama mata pelajaran yang } \\
\text { tidak disukai siswa. Penggunaan metode pembelajaran yang monoton dan kurang menarik juga } \\
\text { ikut mempengaruhi munculnya perilaku off task. Bentuk perilaku off task yang muncul dalam } \\
\text { pembelajaran dapat berupa sikap yang ditunjukkan oleh dalam bentuk verbal (berbicara di luar } \\
\text { materi pelajaran, bernyanyi, berteriak) dalam bentuk non verbal (melamun, tidur, bermain, } \\
\text { menyontek, dan lain-lain). Perilaku off task akan mempengaruhi hasil belajar siswa. Sehingga } \\
\text { perilaku off task ini merupakan indikator minat belajar siswa dalam mengikuti pembelajaran. Oleh } \\
\text { sebab itu, guru perlu memperhatikan sikap dan perilaku siswa dalam mengikuti pembelajarnnya. } \\
\text { Penggunaan metode pembelajaran yang menarik, media pembelajaran yang inovatif, penyusunan } \\
\text { strategi pebelajaran perlu dilakukan oleh guru agar siswa tetap menunjukkan keterlibatan } \\
\text { intelektual-emosional dalam pembelajaran. Guru yang profesional dalam menyiapkan strategi } \\
\text { pembelajaran dan berupaya menanamkan nilai karakter dalam diri siswa melalui pemberian } \\
\text { nasihat, dan teguran langsung yang bersifat mendidik pada siswa yang melakukan perilaku off } \\
\text { task. }\end{array}$ \\
\hline
\end{tabular}

Kata Kunci: Perilaku Off Task, Pembelajaran

\begin{abstract}
The purpose of this study is to provide readers with an understanding of the attitudes and behavior of students who do not support the learning process (off task behavior). Off task behavior that often arises and interferes with the learning process in the classroom. This research is library research, using analytic descriptive analysis. The results of the study show that off-task behavior often occurs in the learning process, especially subjects that students don't like. The use of monotonous and less interesting learning methods also influences the emergence of off-task behavior. The form of off task behavior that arises in learning can be in the form of attitudes shown in verbal form (speaking outside the subject matter, singing, shouting) in the form of non-verbal (daydreaming, sleeping, playing, cheating, etc.). Off task behavior will affect student learning outcomes. So that the behavior of the off task is an indicator of student learning interest in learning. Therefore, teachers need to pay attention to the attitudes and behavior of students in following their learning. The use of interesting learning methods, innovative learning media, preparation of learning strategies need to be done by the teacher so that students continue to show intellectualemotional involvement in learning. Teachers who are professional in preparing learning strategies and strive to instill character values in students through giving advice, and direct teaching that is educational to students who carry out off-task behavior.
\end{abstract}

Keywords : Off Task Behavior, Learning

\section{PENDAHULUAN}

Pada dasarnya manusia adalah makhluk yang unik dan memiliki potensi yang sangat besar.

Manusia dikatakan unik karena setiap manusia itu memiliki kepribadian yang berbeda-beda. Sehingga manusia itu memiliki sifat dan kepribadian yang khas yang menjadikan itu sebagai identitasnya. Selain itu, manusia juga memiliki potensi yang luar biasa. Potensi yang dimiliki manusia 
ini harus dikembangkan supaya manusia itu dapat memenuhi kebutuhannya. Salah satu cara mengembangkan potensinya adalah melalui pendidikan.

Di dalam dunia pendidikan baik itu pendidikan formal ataupun yang non formal, manusia dituntut untuk berfikir dalam rangka mengembangkan potensinya. Belajar adalah salah satu bentuk bahwa manusia itu berfikir. Belajar dapat dilakukan dimana saja, dan kapan saja. Sekolah merupakan salah satu sarana bagi manusia untuk belajar. Siswa merupakan sebutan bagi manusia yang melakukan kegiatan belajar di sekolah. Dalam mengikuti KBM (kegiatan belajar mengajar) setiap siswa mempunyai perilaku sendiri-sendiri. Ada siswa yang memang merasa tertarik dan suka mengikuti kegiatan ini. Ada juga yang mengikuti kegiatan ini tetapi dengan sikap yang negatif. Misalnya berbicara hal-hal di luar materi pelajaran yang dapat merugikan temannya, melamun ketika mengikuti pembelajaran, membuat gaduh saat pelajaran berlangsung, dll.

Proses pembelajaran yang kondusif dan menyenangkan merupakan hal yang diharapkan oleh guru dan siswa. Penerapan metode pembelajaran yang menuntut siswa untuk aktif melakukan kegiatan belajar dengan memanfaatkan segenap potensi yang dimiliki. Interaksi guru dengan siswa terjalin dengan baik, sehingga pembelajaran bukan hanya dua arah namuan multiarah. Akan tetapi hal tersebut sangat bergantung kepada kemampuan guru dalam melaksanakan metode pembelajaran, menyiapkan media pembelajaran, ruangan dan siswa yang antusias dalam mengikuti proses pembelajaran.

Dalam proses pembelajaran terjadi interaksi antara guru dengan siswa. Guru memfasilitasi siswa untuk membantu memahami materi yang disampaikan, siswa berupaya untuk memahami apa yang disampaikan oleh guru. Kondisi seperti ini merupakan kondisi ideal dalam proses pembelajaran klasik (konvensional). Namun keadaan tersebut seringkali terhambat karena munculnya perilaku yang tidak mendukung proses pembelajaran yang dilakukan oleh siswa. Sehingga membuat proses pembelajaran terganggu dan konsentrasi siswa mulai menurun.

Penerapan metode pembelajaran yang tepat juga sangat berdampak kepada perilaku peserta didik. Sesuai dengan amanat Peraturan Pemerintah No 19 tahun 2005 pasal 19 menyatakan bahwa, proses pembelajaran pasa satuan pendidikan diselenggarakan secara interaktif, inspiratif, menyenangkan, menantang, memotivasi peserta didik untuk berpartisipasi aktif serta memberikan ruang yang cukup bagi prakarsa, kreativitas, dan kemandirian sesuai dengan bakat, minat, dan perkembangan fisik serta psikologis peserta didik.

Model pembelajaran yang efektif dengan mempertimbangkan tujuan pembelajaran, materi pembelajaran, ketersediaan fasilitas kondisi peserta didik, dan alokasi waktu yang tersedia. Kemampuan guru dalam mengatur kondisi fisik kelas, misalnya tempat duduk, penggunaan media 
pembelajaran akan menciptakan kondisi yang menaarik perhatian siswa dan memotivasi siswa untuk memperhatikan materi yang akn disampaikan. Maka inovasi dan kreatiifitas guru dalam menerapkan pembelajaran sangat mempengaruhi perilaku yang dtunjukkan oleh siswa saat mengikuti pelajaran.

Perilaku-perilaku negatif tersebut sering dijumpai di sekolah, apalagi ketika saat jam pelajaran yang tidak disukai. Misalnya, Matematika, Bahasa Inggris, Fisika, dll. Perilaku-perilaku yang tidak sesuai dengan pembelajaran merupakan perilaku off-task behavior. Berdasarkan hasil penelitian yang dilaukukan oleh Damiani (2007) menyatakan bahwa hasil penelitian menyebutkan bahwa siswa kelas XII IPA 5 SMA N 3 Bandar Lampung tahun ajaran 2007-2008, pada ujian semester 1 mendapatkan nilai dibawah rata-rata. Hal ini disebabkan salah satunya adalah perilaku yang tidak mendukung pembelajaran pada saat pelajaran berlangsung.

Hal tersebut menandakan bahwa perilaku yang tidak mendukung pembelajaran sangat merugikan dan menghambat proses belajar mengajar. Hal ini tentu tidak diharapkan oleh semua pihak. Perilaku off-task dalam pembelajaran tentunya tidak diharapkan kemunculannya. Hal ini dikarenakan perilaku ini lebih banyak memberikan efek yang negatif bagi siswa. Jika perilaku off-task ini sering muncul dalam pembelajaran, maka dapat dipastikan materi pembelajaran yang disampaikan oleh guru tidak akan sepenuhnya diserap oleh siswa. Pada dasarnya perilaku off-task ini sebagai perilaku yang mengganggu dan menghambat proses pembelajaran.

\section{PEMBAHASAN \\ PERILAKU OFF-TASK}

Menurut Sunawan (2009:6) menyatakan bahwa off-task behavior merupakan bentuk perilaku yang muncul selama proses pembelajaran tetapi tidak mendukung kegiatan belajar. Sedangkan menurut Sukiman (2011) menyatakan bahwa tingkah laku pebelajar dalam situasi belajar di kelas ada yang tidak dikehendaki kemunculannya, yaitu tingkah laku yang disebut off-task behavior. Perilaku off-task merupakan perilaku yang bersifat mengganggu dan tidak diharapkan kemunculannya pada saat kegiatan pembelajaran itu berlangsung.

Perilaku yang tidak mendukung dalam proses pembelajaran dapat berupa perilaku verbal maupun non verbal. Perilaku tersebut muncul secara spontan akibat siswa merasa kurang tertarik dengan mata pelajaran, guru dalam menggunakan metode pembelajaran yang kurang inovatif, sampai kondisi ruangan yang kurang respresentatif. Hal tersebut menunjukkan bahwa daya konsentrasi belajar siswa mulai menurun dan keterlibatan intelektual-emosional siswa mulai berkurang.

Menurut Roberts (2001: 03), menyatakan bahwa penyebab perilaku off-task diantaranya adalah kesulitan kurikulum yang dialami siswa. Pada intinya menyatakan bahwa ketika siswa diberikan 
bahan kurikulum yang relatif sulit untuk tingkat keterampilan siswa, maka presentase perilaku offtask di kelas meningkat. Sebaliknya ketika siswa diberikan bahan di tingkat instruksional akademik maka perilaku off-task menurun presentasenya. Hal tersebut menjelaskan bahwa tingkat kesulitan kurikulum dapat menyebabkan persentase perilaku off-task siswa.

Menurut Hughes (2010: 10) menyatakan bahwa, memahami mengapa siswa berperilaku off-task merupakan faktor penting untuk dipertimbangkan dalam desain dan implementasi sistem bimbingan cerdas. Desain yang tepat dapat berpotensi mengurangi persen siswa menghabiskan waktu off-task. Dalam hal sistem bimbingan cerdas, perilaku off-task yang paling sering ditemukan pada siswa yang memiliki komputer atau tidak suka matematika, menampilkan sikap pasif-agresif, tidak termotivasi untuk berhasil secara akademis, dan cenderung terus berprasangka negatif terhadap guru-guru mereka. Secara khusus, siswa mudah untuk berperilaku off-task juga dapat menampilkan tanda-tanda frustrasi dan biasanya tidak tertarik pada subjek mereka seharusnya belajar (guru).

Dalam hal ini melalui penstrukturan lingkungan belajar oleh guru, karena menurut Sparzo \& Pottet dalam Sukiman (2008:06) ditegaskan bahwa," classroom learning may be defined as a change in student behavior resulting from condition arranged by a teacher”. Berdasarkan paparan di atas, guru dalam proses belajar mengajar disamping harus memperhatikan isi, guru juga harus memperhatikan lingkungan belajar. Karena lingkungan belajar siswa ikut mempengaruhi munculnya perilaku yang tidak diharapkan.

Data tersebut di atas dapat disimpulkan bahwa faktor yang menyebabkan perilaku off task ini muncul adalah; a) Kurikulum yang terlalu sulit bagi siswa; b) Proses pembelajaran yang kurang menarik perhatian siswa; c) Lingkungan belajar yang kurang mendukung. Dalam penelitian ini, perilaku yang ingin diteliti yaitu berbicara diluar materi pembelajaran. Kemungkinan perilaku itu juga dapat disebabkan oleh salah satu faktor diatas.

\section{DAMPAK PERILAKU OFF-TASK}

Menurut Baker (2004) Sebuah studi yang dilakukan pada lima kelas Sekolah Menengah Pertama (SMP) dari dua sekolah yang berbeda, menunjukkan perbedaan yang signifikan dalam jumlah yang siswa belajar ketika mengikuti pelajaran di kelas. Para siswa yang diamati apakah mereka benarbenar belajar saat di kelas atau tidak. Dari hasil pengamatan dua pertiga dari seluruh siswa yang tidak sungguh-sungguh mengikuti pelajaran saat di kelas. Ini menandakan bahwa perilaku off task sangat sering terjadi dalam pembelajaran di kelas.

Perilaku off task sangat berpengaruh terhadap prestasi dan pemahaman siswa dalam mata pelajaran yang diikuti. Berikut yang pernah terjadi di mata pelajaran matematika yang cenderug tidak 
disukai oleh siswa sekolah dasar. Berdasarkan cara pembelajaran klasik (Pembukaan-Inti-Penutup), pada ulangan semester gasal pada lima bidang studi UANAS 2010 di SD 02 Barongan Kudus, diperoleh hasil dengan nilai tertinggi/terendah:

Tabel 1. Perbandingan Nilai Mapel Ujian Nasional

\begin{tabular}{llll}
\hline No & Mata Pelajaran & Nilai Tertinggi & Nilai Terrendah \\
\hline 1. & PPKn & 90 & 60 \\
2. & Bahasa Indonesia & 93 & 59 \\
3. & Matematika & 92 & 35 \\
4. & IPA & 93 & 43 \\
5. & IPS & 97 & 43 \\
\hline
\end{tabular}

Hasil ulangan semester gasal dari ke lima mata pelajaran di atas dari nilai rata-ratanya diketahui tingkat daya serap alih-alih mata pelajaran dari yang kurang dipahami sampai dengan yang dipahami secara tuntas oleh siswa secara urut adalah:

Tabel 2. Tingkat Daya Serap Siswa Tiap Mapel Ujian

\begin{tabular}{llc}
\hline No. & Mata Pelajaran & Tingkat daya serap (\%) \\
\hline 1. & Matematika & 44,46 \\
2. & IPS & 69 \\
3. & Bahasa Indonesia & 75,06 \\
4. & IPA & 79,53 \\
5. & PPKn & 79,8
\end{tabular}

Data disebut di atas menempatkan mata pelajaran matematika sebagai mata pelajaran yang paling rendah diserap oleh siswa. Di sisi lain data hasil angket diketahui bahwa sebenarnya mata pelajaran matematika mendapat porsi perhatian dari anak (55\%). Dan 60\% anak menyatakan senang pada mata pelajaran matematika, dan anak yang secara eksplisit menyatakan tidak senang pada mata pelajaran matematika sebanyak $40 \%$, serta $85 \%$ orang tua terlibat dalam membantu anak belajar matematika di rumah. Secara kualitatif hasil belajar disebut di atas, kecuali mata pelajaran PPKn, didapati adanya anak yang mengalami kesulitan belajar sebagaimana ditunjukkan pada nilai-nilai terendah yang diperoleh siswa. Bertolak dari hasil wawancara dengan guru kelas diperoleh informasi bahwa ada kecenderungan anak bertingkah laku yang tidak mendukung pembelajaran selama terlibat dalam proses belajar-mengajar matematika yang dilaksanakan guru dengan menerapkan model pendekatan klasik. 
Hal ini menandakan bahwa adanya dampak perilaku yang siswa tunjukkan dalam proses pembelajaran dengan pencapaian prestasi belajarnya. Dengan demikian, perilaku off task sangat mempengaruhi siswa dalam memperhatikan dan memahami materi yang disampaikan oleh guru. Dampak perilaku off task ini tidak hanya bagi siswa yang melakukan, namun juga siswa lain yang ada di dalam kelas tersebut. Hal tersebut menandakan bahwa perilaku yang tidak mendukung pembelajaran sangat merugikan dan menghambat proses belajar mengajar.

\section{FAKTOR PENYEBAB}

Sukiman (2011) menyatakan bahwa bertolak dari hasil wawancara dengan guru kelas diperoleh informasi bahwa ada kecenderungan anak bertingkah laku dalam kategori off-task behavior selama terlibat dalam proses belajar-mengajar matematika yang dilaksanakan guru dengan menerapkan model pendekatan klasik. Suatu nuansa penyajian materi pelajaran yang lebih tertuju pada masalah teknik penyelesaian target kurikulum, sementara faktor non-teknik belum mendapat perhatian secara proporsional. Faktor non-teknik di maksud adalah iklim kelas dan lingkungan (ekologi) yang mendukung proses belajar-mengajar.

Faktor lingkungan yang mendukung proses belajar dimungkinkan akan menghambat munculnya perilaku off-task. Hal ini juga dinyatakan oleh Sukiman (2011) menyatakan bahwa "Menurut pandangan behaviorist off-task behavior merupakan hasil belajar dari lingkungannya, dan oleh karena itu pengubahannya menjadi on-task behavior diyakini dapat diupayakan melalui belajar dari lingkungan juga”. Dalam hal ini melalui penstrukturan lingkungan belajar oleh guru, karena menurut Sparzo \& Pottet dalam Sukiman (2011) ditegaskan bahwa: "Classroom learning may be defined as a change in student behavior resulting from condition arranged by a teacher." Berdasarkan paparan di atas guru dalam proses belajar-mengajar di samping harus memperhatikan isi, guru juga harus memperhatikan lingkungan belajar. Karena lingkungan belajar siswa ikut mempengaruhi munculnya perilaku yang tidak diharapkan.

\section{BENTUK PERILAKU OFF TASK}

Sunawan (2009:6) menyatakan bahwa "bentuk perilaku off-task behavior adalah tidak semangat dalam melaksanakan tugas di kelas, berbicara sendiri selama mengikuti pelajaran, menulis atau menggambar yang tidak relevan dengan kajian bidang studi yang sedang diikuti, melanggar tata tertib kelas, menyontek, melamun ketika mengikuti pelajaran, dan lain-lain”. Menurut Hughes (2010: 08) menyebutkan bentuk perilaku off-task yaitu, Dalam kelas siswa dengan mudah dapat mengalihkan perhatian satu sama lain melalui percakapan, catatan yang lewat, dan bahkan bermain game selama 
pelajaran. Sementara komunikasi bisik antara siswa relatif mudah untuk mendeteksi, diam-diam setiap siswa terganggu bisa sulit untuk menemukan. Bahkan tanpa gangguan dari siswa lain, ada banyak cara bagi siswa kelas-terikat untuk ikut serta dalam perilaku 'menghindari tugas. Mereka mungkin tidur, membaca materi tidak berhubungan, atau melakukan beberapa kegiatan lainnya, yang tidak berhubungan seperti bekerja pada pekerjaan rumah bagi kelas yang lain, gambar gambar, dll Ada juga kemungkinan bahwa meskipun mereka tidak melakukan apapun off-tugas tindakan, mereka juga tidak memperhatikan materi yang sedang diajarkan.

Menurut Sparzo dalam Baker (2007:12) memberikan variasi label dalam menggambarkan perilaku off-task seperti, "perilaku impulsive, kurang memperhatikan (inatenttion), tidak menyelesaikan tugas (non completion of task), meninggalkan tempat duduk (out of seat), berbicara tanpa permisi (talking without permission), tidak mempunyai motivasi belajar (unmotived to learn), tidak siap mengikuti kegiatan belajar di kelas (unprepared for class)". Menurut Baker (2007:10), "contoh perilaku off task antara lain: bercakap-cakap dengan siswa lain tentang masalah yang tidak behubungan dengan pelajaran, mengganggu siswa lain, membaca majalah dan lain sebagainya”.

Gambaran diatas merupakan penjelasan mengenai bentuk dan dampak dari perilaku off task yang sering dilakukan oleh siswa. Perilaku yang spontan dilakukan oleh siswa ini teryata memberikan pegaruh yang sangat besar bagi perkembangan akademik siswa. Munculnya perilaku off task ini merupakan bentuk berkurangnya minat belajar pada siswa sehingga keterlibatan intelektualemosional siswa dalam mengikuti pelajaran berkurang.

Sehingga hal ini perlu dipahami oleh guru mata pelajaran, terutama yang diujiankan. Semakin seringnya perilku off task ini muncul dalam pembelajaran, semakin berkurangnya konsentrasi siswa dan berdampak pada hasil belajarnya. Kondisi yang aman, nyaman, dan kompetitif serta menyenangkan merupakan situasi yang diharapkan, maka seorang guru perlu mempersiapkan metode pebelajaran yang cocok dengan materi yang akan disampaikan. Kemampuan guru dalam merencanakan pembelajaran, menyiapkan media pembelajaran, serta komunikatif dan ramah dalam mengajar, memberikan kesempatan siswa untuk mengeksplorasi kemampuannya.

Penurunan perilaku off task ini sangat dipengaruhi oleh faktor pengondisian lingkungan dalam hal ini adalah guru. Menuurut Maulana (2019) Penurunan intensitas perilaku kenakalan remaja didorong dengan pengondisian lingkungan sekolah dan rumah yang mampu memberikan contoh siswa dalam berperilaku sesuai dengan norma di masyarakat. Kenakalan remaja sebagai bentuk siswa mengeksplorasi kemampuan dalam memerankan sesuai gender dan mencari identitas diri dengan cara mengidentifikasi perilaku di sekitarnya. Penyesuaian perilaku remaja memerlukan proses untuk memperoleh perangkat nilai yang diyakini oleh masyarakat. Perilaku off task memang bukan 
termasuk kenakalan remaja, namun sikap dan bentuk perilaku off task ini menandakan bahwa siswa mengalami kesulitan untuk menampilkan perliaku yang sesuai atau perilaku yang diharapkan.

\section{SIMPULAN}

Simpulan yang dapat diambil dalam penjelasan di atas, perilaku sering muncul dalam pembelajaran ini dapat mempengaruhi hasil belajar siswa. Jadi guru mata pelajaran perlu menyikapi hal ini dengan mempersiapkan metode pembelajaran yang interaktif dan menyenangkan. Sebagian besar siswa melakukan perilaku off task dikarenakan minat terhadap pelajaran dan meode pelajaran yang monoton dan kurang bervariasi. Sehingga muncul sikap yang kurang menunjukkan keterlibatan intelektual dalam mengikuti pembelajaran. Mengubah perilaku off task menjadi perilaku on task ini membutuhkan waktu cukup banyak, karena faktor lingkungan dan bawaan dari pribadi siswa saat mengikuti pembelajaran. Sehingga perl pembiasaan yang rutin disertai dengan pemberian reinforcement dalam pembelajaran ataupun reward (hadiah).

Hal tersebut merupakan tantangan bagi guru untuk lebih profesional dalam menyiapkan strategi dalam menyampaikan pembelajaran. Siswa diberikan kesempatan untuk berpendapat, mengeksplorasi kemampuannya melalui pembelajaran yang menyenagkan sehingga perilaku off task ini lambat laun dapat berubah menjadi perilaku on task. 


\section{DAFTAR PUSTAKA}

Baker, Ryan Shaun. dkk. (2004). Off-task Behavior in the Cognitive Tutor Classroom: When students “Game the Sistem”. USA: Carnegie Mellon University . (2007). Modeling and Understanding Students Off-Task Behavior in Intelligent Tutoring Systems. USA: University of Nottingham

Clevenger. Rebecca Pate. dkk. (2008). Improvement of Off-Task Behavior of Elementary and High School Students Through The Use of Cooperative Learning Startegies. Illinois: Saint Xavier

Corey. Gerald. (2007). Teori dan Praktek dari Konseling dan Psikoterapi. Translated by: E. Koswara. Bandung: PT. Refika Aditama

Hughes. Kristen. (2010). Educational Software for Off-Task Behavior. USA: Worcester Polytechnic Institute.

Maulana, M., Nugroho, P. (2019). MENGURANGI KENAKALAN REMAJA MENGGUNAKAN KONSELING BEHAVIORAL PADA PESERTA DIDIK DI SMA. Konseli: Jurnal Bimbingan dan Konseling, 6(1). Retrieved from http://ejournal.radenintan.ac.id/index.php/konseli/article/view/4059/2941

Roberts. Maura.(2005). Off-Task Behavior in the Classroom Applying FBA and CBM.University of Oregon

Sunawan.(2007). Hand Out: Diagnosa Kesulitan Belajar. Semarang: Tidak diterbitkan Sugiyono. (2010). Metodologi Penelitian Kuantitatif Kualitatif dan R\&D. Bandung: Alfabeta 